\title{
ROZUMIENIE GODNOŚCI CZLOWIEKA I JEJ ZNACZENIE W PROCESIE STANOWIENIA I STOSOWANIA PRAWA. PROPOZYCJA TESTU ZGODNOŚCI REGULACJI PRAWNYCH Z ZASADĄ GODNOŚCI CZLOWIEKA ${ }^{1}$
}

\author{
UNDERSTANDING HUMAN DIGNITY AND ITS ROLE IN THE PROCESS \\ OF LAWMAKING AND APPLYING THE LAW. A PROPOSAL FOR \\ A COMPLIANCE TEST OF LEGAL REGULATIONS \\ WITH THE PRINCIPLE OF HUMAN DIGNITY
}

In the Preamble of Constitution of the Republic of Poland the inherent dignity of the person is a value that limits application of all norms, including the constitutional ones. Human dignity referred to therein is dignity of a human being - the core of humanity present in any person, inherent, inalienable and inviolable. The article presents the interpretation of the notion of "human dignity" in the jurisprudence of the Constitutional Tribunal and the Supreme Court. In the conclusion, the author proposes a compliance test for the existent and draft legal regulations with the constitutional principle of human dignity.

Słowa kluczowe: godność człowieka, wykładnia konstytucji, zasady konstytucyjne, orzecznictwo Trybunału Konstytucyjnego, orzecznictwo Sądu Najwyższego

Key words: human dignity, statutory interpretation of the Constitution, constitutional principles, Constitutional Court judicature, Supreme Court judicature

* Sebastian Zieliński, Uniwersytet w Białymstoku, Wydział Prawa, Katedra Postępowania Karnego, sebastian.zielinski@protonmail.com, https://orcid.org/0000-0002-8443-8944

\section{WPROWADZENIE}

T stawodawca podkreślił szczególną pozycję godności człowieka w systemie prawnym Rzeczypospolitej Polskiej, nadając jej w preambule konstytucji ${ }^{2}$ status wartości limitującej stosowanie wszystkich norm, w tym konstytucyjnych. Ta „funkcja” godności człowieka bywa nazywana zasadą godności człowieka. Preambuła konstytucji została napisana w sposób odbiegający od wymogów techniki legislacyjnej, był to jednak zabieg celowy. Stanowi ona normatywną syntezę ustawy zasadniczej, ,wyraża esencję wartości i zasad znajdujących potwierdzenie i rozwinięcie

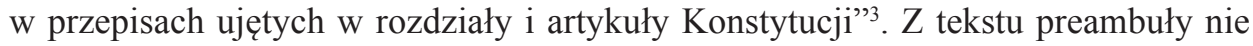

${ }^{1}$ Artykuł został napisany w ramach projektu „Wpływ zasady godności człowieka na konstrukcję odpowiedzialności w prawie karnym", finansowanego przez Narodowe Centrum Nauki (nr projektu 2015/19/D/HS5/00526).

${ }^{2}$ Konstytucja Rzeczypospolitej Polskiej z dnia 2 kwietnia 1997 r., Dz.U. nr 78, poz. 483.

${ }^{3}$ B. Zdziennicki, Wprowadzenie, [w:] Preambuła Konstytucji Rzeczpospolitej Polskiej, „Studia i Materiały Trybunału Konstytucyjnego" 2009, nr XXXII, s. 7. 
sposób wyprowadzić normy prawne w znaczeniu ścisłym. Niemniej jednak dostarcza ona opartych na autentycznej wypowiedzi ustrojodawcy wskazówek co do zgodnych z jego intencjami kierunków interpretacji przepisów części normatywnej konstytu$\mathrm{cji}^{4}$. Uznanie normatywnego charakteru każdej regulacji konstytucyjnej, włącznie z preambułą, stanowi zatem podstawowe założenie, które należy przyjąć jako punkt wyjścia w zakresie analizy roli zasad konstytucyjnych w porządku prawnym Rzeczypospolitej ${ }^{5}$. Należy zaaprobować wyrażany w doktrynie pogląd, że status nadany godności człowieka w preambule konstytucji ,wskazuje na jej systemowe powiązanie nie tylko z prawami i wolnościami człowieka, lecz z zasadami prawa przedmiotowego, w szczególności zasadami naczelnymi Konstytucji”. Godność stanowi wartość wyznaczającą właściwy kierunek wykładni i stosowania konstytucji — wszystkie jej przepisy należy interpretować $\mathrm{w}$ duchu poszanowania przyrodzonej godności człowieka.

Zasada godności człowieka, jako zasada konstytucyjna, jest wyprowadzana ponadto przede wszystkim z art. 30 konstytucji, który „stanowi jedno z głębszych wyrażeń godności człowieka we współczesnym konstytucjonalizmie". Przepis art. 30 konstytucji określa samodzielną normę prawną, która rozstrzyga o uznaniu człowieka za podmiot prawa oraz o bezwzględnej i równej ochronie tej podmiotowości, a sam ten przepis ma charakter bezwzględnie obowiązujący i należy go zaliczyć do podstawowych zasad ustrojus.

Czym jest zatem „godność człowieka”, co należy rozumieć przez to pojęcie? Jaki ma zakres przedmiotowy, podmiotowy i czasowy? Jakie ograniczenia i na kogo nakłada „zasada godności człowieka”? Udzielenie odpowiedzi na te pytania ma fundamentalne znaczenie w procesie stanowienia i stosowania prawa. W konsekwencji uprawniona jest teza, że „godność człowieka” powinna odgrywać pierwszoplanową rolę w procesie kontroli konstytucyjności aktów prawnych oraz nadzoru nad działalnością sądów powszechnych i wojskowych w zakresie orzekania.

Celem niniejszego opracowania jest przedstawienie rozumienia pojęcia „godności człowieka" w orzecznictwie Trybunału Konstytucyjnego [dalej: TK, Trybunał] odnoszącym się do art. 30 konstytucji oraz w orzecznictwie Sądu Najwyższego [dalej: SN], jako ustrojowych strażników prawidłowego stanowienia i stosowania prawa. Pojęcie „godność człowieka” nie jest jednak osiągnięciem doktryny prawniczej i judykatury. Dlatego analizę orzecznictwa poprzedza synteza poglądów wybranych przedstawicieli doktryny filozoficznej i prawniczej w tym zakresie. W konkluzjach przedstawiono propozycję testu zgodności obowiązujących i proponowanych regulacji prawnych z wymaganiami wynikającymi z zasady godności człowieka.

${ }^{4}$ Wyrok TK z 11 maja 2005 r., sygn. akt K 18/04, OTK ZU 2005/5A/49.

${ }_{5}^{5}$ Vide, Konstytucja RP, t. I, Komentarz do art. 1-86, red. M. Safjan, L. Bosek, Warszawa 2016, s. 74.

${ }^{6}$ L. Bosek, uwagi do art. 30, [w:] Konstytucja RP, t. I..., s. 727.

7 Granat M., Godność człowieka z art. 30 Konstytucji RP jako wartość i jako norma prawna, „Państwo i Prawo" 2014, z. 8, s. 19.

${ }^{8}$ L. Bosek, uwaga do art. 30, [w:] Konstytucja RP, t. I..., s. 725. 


\section{ZNACZENIE POJĘCIA „GODNOŚĆ CZLOWIEKA” W POGLĄDACH PRZEDSTAWICIELI DOKTRYNY}

„Godność”, w tym także „godność człowieka”, to pojęcia wieloznaczne. Mówiąc o godności człowieka, możemy mieć na myśli np. jego poczucie własnej wartości i wewnętrzne przekonanie o swojej moralności, stanowisko, które zajmuje, albo po prostu nazwisko9. Przed przeprowadzeniem analizy wpływu godności osobowej człowieka na wykładnię przepisów prawa należy przede wszystkim ustalić, która to „godność człowieka" stanowi omawianą nadrzędną wartość konstytucyjną. Marek Piechowiak przedstawił podział typów godności człowieka najbliższy tym, które można odnaleźć w porządku prawnym Rzeczpospolitej Polskiej. Autor ten dokonał podziału godności człowieka na cztery rodzaje: godność osobistą, osobowościową, ugruntowaną w okolicznościach życia oraz osobową ${ }^{10}$. Godnością osobistą jest ten najbardziej intuicyjny jej rodzaj — „dobre imię”, „,honor”, ,poczucie własnej wartości”, „,szacunek do samego siebie”. Tomasz Hobbes postrzegał godność osobistą jako ,publiczną wartość człowieka, która jest wartością, jaką mu przypisuje państwo i społeczność, jest tą wartością, którą ludzie nazywają dostojeństwem" "11. Godność osobista rozumiana jest jako sfera osobowości kształtowana przez szereg okoliczności zewnętrznych, która konkretyzuje się w poczuciu własnej wartości człowieka i oczekiwaniu szacunku ze strony innych ludzi ${ }^{12}$. To wewnętrzne przekonanie człowieka o swoim moralnym i etycznym nieposzlakowaniu oraz czci, jako wyrazu pozytywnego ustosunkowania się innych ludzi do jego wartości osobistej i społecznej ${ }^{13}$.

Tak rozumiana godność może być warunkowana historycznie i kulturowo. Zmienny jest jej zakres i charakter, który zależy od psychiki i osobowości każdego człowieka, a także zaakceptowanego przez niego systemu wartości, środowiska, w którym funkcjonuje, pozycji społecznej, którą zajmuje, jak i tej, do której aspiruje. Godność osobista człowieka może zostać naruszona przez działanie innego podmiotu, którego skutkiem jest zmiana postrzegania tego człowieka na gorsze, a w konsekwencji traktowanie go w sposób nienależyty, nieprzystający do tego, co ten człowiek sobą reprezentuje ${ }^{14}$. W orzecznictwie godność osobista człowieka jest przywoływana najczęściej właśnie w kontekście naruszenia dóbr osobistych, chociaż judykatura postrzega godność osobistą człowieka i jego dobre imię jako wartości należące do odrębnej kategorii dóbr

${ }^{9}$ Hasło: „godność”, [w:] Słownik języka polskiego, t. 1: A-K, red. M. Szymczak, Warszawa 1988, s. 673.

${ }^{10}$ M. Piechowiak, Filozofia praw człowieka - Prawa człowieka w świetle ich międzynarodowej ochrony, Lublin 1999, s. 343 i n.; vide idem, Klasyczna koncepcja osoby jako podstawa pojmowania praw człowieka. Wokół Tomasza z Akwinu i Immanuela Kanta propozycji ugruntowania godności człowieka, [w:] Prawo naturalne - natura prawa, red. P. Dardziński, F. Longchamps de Bérier, K. Szczucki, Warszawa 2011, s. 3-20.

${ }_{11}$ T. Hobbes, Lewiatan czyli materia, forma i władza państwa kościelnego i świeckiego, Warszawa 2005, s. $167-168$.

${ }_{12}$ Wyrok SN z 25 kwietnia 1989 r., sygn. akt I CR 143/89, OSP 1990/9/330.

${ }_{13}$ Wyrok SN z 21 marca 2007 r., sygn. akt I CSK 292/06, Legalis nr 156746.

${ }^{14}$ M. Piechowiak, Filozofia..., s. 349 i n. 
osobistych $^{15}$. Co istotne, przyjmuje się, że granice ochrony godności osobistej człowieka są przesuwalne. Powszechnie akceptowany jest pogląd o konieczności znoszenia przez osoby publiczne krytyki o większym nasileniu, ostrzejszej w formie, stanowiącej nieunikniony element dysputy politycznej ${ }^{16}$.

Podsumowując atrybuty godności osobistej człowieka, należy wskazać, że jest ona naruszalna, ma zmienny charakter i zakres, a przy tym próg jej naruszenia wyznaczają: wrażliwość, psychika, osobowość, środowisko, a nawet aktywność społeczna i polityczna podmiotu, który ją posiada. W konsekwencji wydaje się oczywiste, że godność osobista człowieka nie jest tym rodzajem godności, o której mowa w preambule i art. 30 konstytucji. Godność osobista nie ma jej podstawowych przymiotów: nienaruszalności faktycznej i niezbywalności, a także powszechności oraz równości.

Kolejny typ godności, tj. godność ugruntowana w okolicznościach życia, może się przejawiać w działaniach innych ludzi lub w wolności człowieka do działania w określony sposób - to stan, w którym człowiek w pełni realizuje własne człowieczeństwo ${ }^{17}$. Ten rodzaj godności odnosi się do warunków życia człowieka, które możemy określać jako godne albo niegodne. Tytułem przykładu o godnych warunkach życia może decydować dostęp do: bieżącej wody, ogrzewania, czystego powietrza, technologii czy edukacji, wolność poruszania się, wolność decydowania o miejscu zatrudnienia czy możliwość samorealizacji. Godność wynikająca z okoliczności życia również nie posiada podstawowych przymiotów tej godności, o której mowa w konstytucji: przyrodzoności, nienaruszalności i niezbywalności. Nie ma zatem wątpliwości, że to nie temu rodzajowi godności ustawodawca nadał rolę ,niewzruszonej podstawy Rzeczypospolitej Polskiej"18.

Następny rodzaj godności, czyli godność osobowościowa, jest „związana z doskonałością moralną — nabywana lub tracona jest poprzez własne postępowanie (decyzje) jej podmiotu"19. Na posiadanie godności osobowościowej trzeba zasłużyć własnymi czynami. Jak stwierdziła Maria Ossowska, „ma godność ten, kto umie bronić pewnych uznanych przez siebie wartości, z których obroną związane jest jego poczucie własnej wartości" ${ }^{20}$. Nie jest zatem ona przyrodzona i bez wątpienia jest naruszalna. Na tej konstatacji można by zakończyć uzasadnienie odnośnie do tego, dlaczego konstytucyjna zasada godności człowieka nie odnosi się do tego rodzaju godności. Jedynie dodatkowo należy wskazać, że duża zmienność zakresu godności osobowościowej na różnych etapach życia człowieka również świadczy przeciwko przyznaniu jej pozycji konstytucyjnego fundamentu wszystkich praw i wolności.

Najdonioślejszym rodzajem godności człowieka jest jego godność osobowa, a jej właściwych fundamentów zwykle poszukuje się w nauczaniach św. Tomasza

\footnotetext{
15 Wyrok SN z 27 czerwca 2012 r., sygn. akt IV CSK 389/11, Legalis nr 551906.

16 Wyrok SN z 14 stycznia 2015 r., sygn. akt II CSK 296/14, Legalis nr 1200679.

17 M. Piechowiak, Filozofia..., s. 347.

18 M. Piechowiak, Komentarz..., s. 150.

19 Ibidem, s. 346.

${ }^{20}$ M. Ossowska, Normy moralne w obronie godności człowieka, „Etyka” 1969, nr 5, s. 12.
} 
z Akwinu. Według jego koncepcji pojęcie osoby jest nierozerwalnie związane z pojęciem godności, „osobą jest to, co posiada godność (persona est nomen dignitatis)”21. Godność ma w tej koncepcji znaczenie szczególne. Jak wskazał M. Piechowiak, objaśniając filozofię Akwinaty, ,nazwa «osoba» przysługuje ze względu na godność, a ta ugruntowana jest nie w samej rozumności jako właściwości człowieka, ale w samoistnieniu w pewien szczególny sposób (właściwy istotom rozumnym)"²2. Immanuel Kant wskazywał, że godność stanowi wartość nieprzeliczalną na inne dobra, niemierzalną innymi wartościami: „w państwie celów wszystko ma albo jakąś cenę, albo godność. To, co ma cenę, można zastąpić także przez coś innego, jako jego równoważnik, co zaś wszelką cenę przewyższa, a więc nie dopuszcza żadnego równoważnika, posiada godność” ${ }^{23}$. Według Kanta to, co posiada wartość wewnętrzną, tj. godność (chociażby obok wartości względnej, np. ceny) może być jedynie celem samym w sobie, a nie może być środkiem do innego celu. Taką wartość ma każdy człowiek i tę wartość nazywamy godnością osobową. Godność człowieka stanowi zatem właściwość każdej osoby, sprowadzającą się do tego, że człowiek zawsze jest postrzegany jako cel sam w sobie, nigdy jako środek do osiągnięcia jakiegokolwiek — chociażby najbardziej doniosłego - celu.

Przywołane koncepcje zostały rozwinięte przez przedstawicieli filozofii personalistycznej, którzy pojęcia „osoba ludzka” i ,godność osoby ludzkiej” uznali za podstawową kategorię tego nurtu filozoficznego ${ }^{24}$. Fundamentalnym dobrem, które jest w tej filozofii chronione, jest niezbywalna i niepowtarzalna godność człowieka ${ }^{25}$. Godność ta oznacza ,przede wszystkim właściwość lub też podstawową jakość i w tym znaczeniu «wartość» osoby jako takiej: wartość, która przysługuje człowiekowi z tej racji, że jest osobą, o którą człowiek z tej właśnie racji powinien zabiegać” ${ }^{26}$. „Każdy człowiek posiada godność i mieszcząc się w granicach ludzkiego gatunku - przez wrodzoną godność - występuje poza jego granice, aby stanowić każdy dla siebie odrębny świat przeżyć, twórczości i celów ${ }^{27}$. Dlatego człowiek jest w ogóle nieporównywalny do innych istot $\mathrm{w}$ aspekcie wartości, ponieważ „nie mówimy o wartości człowieka, lecz o jego godności. Jeśli nawet wartość życia dziesięciu ludzi jest większa niż wartość jednego człowieka, to godność dziesięciu ludzi nie jest większa niż godność jednego człowieka. Osoby nie są «dodawalne»”"28. W konsekwencji godność osobowa człowieka jest niepodzielna i nienaruszalna, a uszanowanie godności jest sprawą publiczną, nie zależy od indywidualnego osądu sumienia. Stanowi ona

${ }^{21}$ L. Bosek, Gwarancje godności ludzkiej i ich wplyw na polskie prawo cywilne, Warszawa 2012, s. 35 .

${ }^{22}$ M. Piechowiak, Klasyczna..., s. 6.

${ }_{23}$ I. Kant, Uzasadnienie metafizyki moralności, Warszawa 1971, s. 70.

24 L. Bosek, Gwarancje..., s. 43.

25 R. Czekalski, Personalistyczna pedagogika wychowawcza Jana Pawła II, „,Warszawskie Studia Teologiczne" 2008, t. XXI, s. 183-190.

${ }^{26}$ K. Wojtyła, Człowiek w polu odpowiedzialności, Rzym-Lublin 1991, s. 50.

${ }^{27}$ K. Wojtyła, Rozważania o istocie człowieka, Kraków 2003, s. 97.

28 R. Spaemann, Osoby - o różnicy między kimś a czymś, Warszawa 2001, s. 246. 
wartość pierwotną w odniesieniu do każdego systemu etycznego ${ }^{29}$. Godność osobowa człowieka jest zasadą źródłową wobec podstawowych zasad bytu społecznego będących wspólnym mianownikiem całych grup praw człowieka, nawet tych jeszcze niezdefiniowanych ${ }^{30}$.

Jak zauważył Adam Rodziński, ,jeżeli prawdą jest, że nie można zrozumieć, na czym polega wrodzona człowiekowi godność, bez wzięcia pod uwagę natury człowieka, to równie prawdą jest, że nie można zdobyć właściwego pojęcia o człowieku, i o jego naturze, nie pamiętając równocześnie o tym, że człowiek — i to każdy bez wyjątku — jest osobą i że z tej racji przysługuje mu niezależnie od tego, co czyni i jak postępuje, godność trwała, niezbywalna i zobowiązująca"31. Rodziński twierdzi także, że godności jako pojęcia pierwotnego zdefiniować się nie da i wszelkie próby jej definicji muszą zakończyć się niepowodzeniem ${ }^{32}$. Przyjęcie założenia o niedefiniowalności pojęcia „godność” utrudnia prawidłową interpretację przepisów zgodną z jej duchem. Słusznie wskazuje się jednak, że o ile dotychczas nie udało się wypracować jednolitej definicji godności człowieka, o tyle w regulacjach, w których zadeklarowano godność człowieka, w tym w instrumentach ochrony praw człowieka, zawarta jest charakterystyka godności mogąca być „punktem wyjścia do określenia rzeczywistości, o której się orzeka przy użyciu kategorii «godność»" ${ }^{33}$.

Z przedstawionych rozważań wynika, że godność osobowa człowieka ma pewne stałe przymioty - przysługuje ona każdemu człowiekowi od początku jego człowieczeństwa (przyrodzoność), niezależnie od jego czynów i czynów innych osób (nienaruszalność) i jako taka jest niezbywalna i nieprzenoszalna oraz jest wartością niestopniowalną. To właśnie o godności osobowej człowieka jest mowa w konstytucji. Tak rozumiana godność osobowa człowieka to rdzeń człowieczeństwa. Koncepcja godności została zaakceptowana jako źródło wszelkich praw i wolności człowieka, pozwalające na ominięcie wartościowania prawnonaturalnego czy prawnopozytywnego, lewicowego albo prawicowego, moralnego albo religijnego. Ta godność to konstrukcja aksjologicznie uzasadniająca wszystkie fakty społeczne i zachowania, które podejmujemy, w tym normy prawne. „Godność ludzka, o którą tu chodzi, to po prostu sama osoba jako wartość" ${ }^{34}$. Zgodnie z art. 30 konstytucji, przyrodzona i niezbywalna godność człowieka stanowi źródło wolności i praw człowieka i obywatela. Jest ona nienaruszalna, a jej poszanowanie i ochrona jest obowiązkiem władz publicznych. Nienaruszalność godności należy — za M. Piechowiakiem — przedstawić w dwóch aspektach: nienaruszalności w sensie opisowym i normatywnym ${ }^{35}$.

${ }^{29}$ M. Wojewoda, Natura ludzka i wolność w ujęciu Roberta Spaemanna, [w:] Szkice o godności człowieka, red. M. Piechowiak, T. Turowski, Zielona Góra 2012, s. 163.

${ }^{30}$ P. Borkowski, Godność osoby ludzkiej — zasada zasad społecznych, [w:] Jan Pawet II Promotorem godności człowieka, red. A. Bałabucha, Świdnica 2007, s. 118.

31 A. Rodziński, U podstaw kultury moralnej, Warszawa 1999, s. 103.

32 A. Rodziński, Osoba, moralność, kultura, Lublin 1989, s. 98.

${ }^{33}$ M. Piechowiak, Filozofia..., s. 79-80.

34 A. Rodziński, Wprowadzenie..., s. 127.

35 Vide M. Piechowiak, Dobro wspólne..., s. 341 
Pierwsza sprowadza się do przedstawienia godności jako rdzenia człowieczeństwa, nienaruszalnej istoty uznania człowieka za osobę ludzką ze wszystkimi jej prawami i wolnościami. Podnosi się, że ta właściwość godności stanowi w istocie „faktyczny brak możliwości pozbawienia kogoś godności lub jej umniejszenia”, a zatem „to nic innego jak przyrodzoność i niezbywalność, o których mówi pierwsze zdanie art. 30"36.

W tym kontekście należy poczynić pewne uwagi. Przyrodzoność oznacza, że każda osoba ludzka jest wyposażona w godność wynikająca z samego faktu bycia człowiekiem, nie jest ona zatem nadawana. Niezbywalność oznacza, że osoba nie może w jakikolwiek sposób przenieść godności lub jej się zrzec. Godność ma każdy człowiek. Natomiast wspomniana nienaruszalność nie stanowi powtórzenia wymienionych cech, ale ma za zadanie podkreślić niepodzielność godności. Godność — oprócz tego, że stanowi przymiot każdego człowieka i nikt nie może się jej pozbyć w całości jest jeszcze równa, niepodzielna. Każdy człowiek ma tyle samo przyrodzonej godności i w tym sensie nie można jej naruszyć. W konstytucji posłużono się terminem „godność człowieka”, nie zaś „godność obywatela”, a zatem obowiązek jej poszanowania jest równie aktualny wobec każdego człowieka pozostającego w jej jurysdykcji, bez względu na obywatelstwo, pochodzenie, rasę czy jakiekolwiek inne cechy. Nienaruszalność normatywna godności sprowadza się do nakazu adresowanego do władz publicznych, dla której stanowi ona wartość nieinstrumentalną i „nie powinna być nigdy poświęcana dla realizacji innych dóbr i stąd nie powinna być ważona względem innych wartości” ${ }^{37}$. Wykładnia przepisów konstytucji nie może skutkować wyprowadzeniem norm, których zastosowanie stanowiłoby działanie skierowane przeciwko godności człowieka. M. Piechowiak słusznie wskazał, że „skoro Rzeczpospolita Polska ma być dobrem wspólnym, zatem sumą społecznych warunków rozwoju członków wspólnoty politycznej, to pierwszą podstawą określenia tych warunków jest przyrodzona godność i postanowienia rozdziału II" ${ }^{\prime 3}$.

Ujęcie godności człowieka w konstytucji nie jest warunkiem jej uznania w prawie, a jej nadrzędna wartość w systemie prawnym nie musi wynikać z uwzględnienia jej $\mathrm{w}$ przepisach ${ }^{39}$. Z powodu zaznaczenia przyrodzonego charakteru godności człowieka jest jasne, że w przepisach ustawy zasadniczej nie ukonstytuowano godności człowie$\mathrm{ka}$, ale zadeklarowano istnienie tej wartości konstytucyjnej i unormowano bezwzględny obowiązek jej poszanowania.

Wyczerpującej syntezy poglądów przedstawicieli doktryny na temat przymiotów konstytucyjnej godności człowieka oraz częściowo jej pozycji w hierarchii wartości ustawy zasadniczej dokonał Leszek Bosek, nazywając gwarancję godności ludzkiej

36 Ibidem.

37 Ibidem.

${ }^{38}$ M. Piechowiak, uwaga do preambuły, [w:] Konstytucja RP... Autor proponuje, aby takie stanowisko uznać za linię obrony godności człowieka jako wartości podstawowej, jednocześnie podnosi, że struktura preambuły nie daje wystarczających podstaw do uznania godności za najwyższą wartość porządku konstytucyjnego RP.

${ }^{39}$ Granat M., Godność czlowieka z art. 30..., s. 20 
„zasadą konstytucyjną, zasadą zasad, której przydajemy walor absolutny i niezaprzeczalny, podstawową zasadą konstytucyjną, zasadą fundamentalną Konstytucji, zasadą porządku konstytucyjnego, «przewodnią zasadą konstytucyjną», «najwyższą zasadą konstytucyjnego obiektywnego Prawa», «ideą przewodnią Konstytucji», zasadą ogólną dotyczącą wolności i praw człowieka, zasadą całego porządku prawnego" ${ }^{40}$. Godność jest „najwyższym celem prawa oraz przewodnią zasadą konstytucyjną ustroju państwowego", której obecność w procesie stanowienia i stosowania prawa jest niezbędna ${ }^{41}$.

Krystian Complak, określając godność osoby ludzkiej wprost jako „najwyższą wartość całego porządku konstytucyjnego", zaznaczył, że jest ona uzasadnieniem i podstawą ,przyrodzonych i niezbywalnych” swobód i praw, które przysługują niezależnie od ustawodawcy, nie mogą zatem przez ustawodawcę zostać nikomu odebra$n \mathrm{e}^{42}$. Autor ten w wyniku pogłębionej analizy znaczenia godności człowieka w ustroju Rzeczypospolitej zrewidował nieco swój pogląd, podnosząc, że godność nie jest jednak fundamentem całego porządku prawnego w Polsce i — co ważniejsze — aby mogła stać się przedmiotem efektywnej ochrony prawnej, musi być ściśle określona ${ }^{43}$. Ta godność człowieka to ogół niepowtarzalnych przymiotów istoty ludzkiej, odróżniających ją od świata zwierzęcego i roślinnego ${ }^{44}$. Konieczność dookreślenia pojęcia „godność człowieka” podkreślał także Mirosław Granat, wskazując, że bez rozeznania, „co oznacza godność człowieka w prawie, to mimo umieszczenia jej zarówno na początku rozdziału II Konstytucji, jak i w Preambule, będzie ona postrzegana raczej jako «doniosłe hasło», aniżeli «kamień węgielny naszego systemu prawa»" ${ }^{45}$.

Chociaż w doktrynie dominuje stanowisko o prymacie godności człowieka wśród dóbr konstytucyjnych, to można spotkać stanowiska przeciwne. Przykładem jest nie tylko przywołany już pogląd K. Complaka. Także M. Piechowiak wskazuje, że to dobro wspólne jest nadrzędną wartością konstytucyjną. Podkreśla jednocześnie, że jest to wyrażenie idiomatyczne, błędnie interpretowane w doktrynie i orzecznictwie $\mathrm{TK}^{46}$. Autor ten przywołuje szereg argumentów na poparcie swojego stanowiska, podkreślając przede wszystkim umiejscowienie pojęcia „,dobro wspólne” w konstytucji. Podkreśla przy tym, że „nienaruszalność godności jest podstawą postulatu, aby nadając RP

${ }^{40}$ Vide L. Bosek, Gwarancje..., s. 144 oraz zacytowane i przedstawione tam poglądy B. Lewaszkiewicz-Petrykowskiej, M. Wyrzykowskiego, K. Complaka, B. Gronowskiej, K.E. Heina, G. Düriga, P. Sarneckiego, A. Młynarskiej-Sobaczewskiej, D. Dudka.

41 Borski M., Godność człowieka jako wartość uniwersalna, „Przegląd Prawa Publicznego” 2014, nr 3, s. 13 .

42 K. Complak, Uwagi o godności człowieka oraz jej ochrona w świetle nowej Konstytucji, „Przegląd Sejmowy" 1998, nr 5, s. 43.

${ }^{43}$ Complak K., Godność nie jest dobra na wszystko. Propozycja uporzadkowania materii, [w:] Minikomentarz dla maksiprofesora: księga jubileuszowa profesora Leszka Garlickiego, red. M. Zubik, Warszawa 2016, s. 239.

44 Complak K., Godność nie jest..., s. 244.

${ }^{45}$ Granat M., Godność czlowieka..., s. 3.

46 Vide M. Piechowiak, Stużebność państwa wobec człowieka i jego praw jako naczelna idea Konstytucji RP, „Przegląd Sejmowy” 2007, nr 4, s. 84 i n. 
kształt dobra wspólnego, dookreślając i tworząc społeczne warunki rozwoju, nie traktować żadnego człowieka czysto instrumentalnie [...] godność ma pierwszeństwo także w takim sensie, że stanowi ugruntowanie (w sensie ontologicznym) i uzasadnienie (z argumentacyjnego punktu widzenia) prawnonaturalnego charakteru dobra wspólnego" ${ }^{47}$. Ostatecznie autor ten dochodzi do wniosku, że „analizując zależności między dobrem wspólnym a godnością, można postawić tezę o współzależności koncepcji dobra wspólnego i koncepcji godności - pojmowanie dobra wspólnego współdeterminuje pojmowanie godności, a pojmowanie godności współdeterminuje pojmowanie dobra wspólnego" ${ }^{48}$. Zajmując takie stanowisko, podkreśla tym samym wagę godności człowieka jako wartości konstytucyjnej.

Status godności człowieka został dookreślony w art. 30 konstytucji, gdzie uwzględniając treść preambuły — nadano jej właściwą, pierwszoplanową rolę w zakresie stosowania i interpretacji wszystkich przepisów polskiego prawa ${ }^{49}$. Należy się jednak zgodzić z tymi autorami, którzy twierdzą, że zasada godności człowieka nie wyznacza samych celów Rzeczypospolitej. Podstawowe cele należy bowiem postrzegać przez pryzmat art. 1 oraz 5 konstytucji, tj. przez pryzmat dobra wspólnego ${ }^{50}$. Nie ma jednak wątpliwości, że to godność człowieka wyznacza zbiór środków — i granice dopuszczalności ich stosowania - w zakresie dochodzenia przez państwo do tych celów, szczególnie tam, gdzie wolności oraz prawa człowieka i obywatela są zagrożone naruszeniem. Co więcej, godność człowieka jest niezbędna w procesie dekodowania celów Rzeczypospolitej, albowiem fundamentem dobra wspólnego jest „człowiek zmierzający do osobowego rozwoju, mówiąc tradycyjnie, do szczęścia ze swymi przyrodzonymi prawami jako podstawowymi warunkami takiego rozwoju; a państwo ma przyjąć taki a nie inny kształt ze względu na człowieka i jego prawa"s1.

\section{ZNACZENIE POJECCIA „GODNOŚĆ CZLOWIEKA” W ORZECZNICTWIE TRYBUNALU KONSTYTUCYJNEGO}

Ustrojodawca nadał godności człowieka znaczenie konstytucyjne, czyniąc z niej punkt odniesienia dla systemu wartości, wokół którego zbudowano konstytucję, oraz fundament całego porządku prawnego w państwie ${ }^{52}$. Godność osobowa jako konstytucyjne źródło wolności i praw człowieka i obywatela stanowi podstawę wykładni wszystkich wolności i praw człowieka i obywatela, przez co - w konsekwencji — powinna ona mieć kluczowe znaczenie w procesie wykładni przepisów prawa

${ }^{47}$ M. Piechowiak, Dobro wspólne jako fundament polskiego porządku konstytucyjnego, Warszawa 2012, s. 351.

${ }^{48}$ Ibidem.

${ }^{49}$ Według M. Piechowiaka, artykułem 30 konstytucji nie nadano godności pozycji nadrzędnej, taką pozycję nadano godności człowieka pośrednio art. 1; vide M. Piechowiak, Dobro wspólne jako fundament..., s. 351; idem, Piechowiak, Prawne a pozaprawne pojęcia dobra wspólnego, [w:] Dobro wspólne. Teoria i praktyka, red. W. Arndt, F. Longchamps de Bérier, K. Szczucki, Warszawa 2013, s. 39-40.

${ }^{50}$ Vide np. M. Piechowiak, Dobro wspólne jako fundament..., s. 346-347.

${ }^{51}$ M. Piechowiak Stużebność państwa..., s. 88.

52 Pogląd wyrażony w wyroku TK z 23 marca 1999 r., sygn. akt K 2/98, OTK 1999/3/38. 
i orzekania przez sądy i trybunały. TK podkreślił, że już we wstępie do konstytucji wskazano, iż jej stosowaniu powinna towarzyszyć dbałość o zachowanie przyrodzonej godności człowieka. Godność nie może być rozumiana jako cecha czy też zespół praw nadanych przez państwo, jest ona bowiem w stosunku do państwa pierwotna. Zarówno ustawodawca, jak i organy stosujące prawo muszą zatem respektować treści zawarte w pojęciu ,godność”, która przysługuje każdemu człowiekowi ${ }^{53}$. Szczególnie istotne jest to, jak zasada godności człowieka jest interpretowana w orzecznictwie Trybunału odnoszącym się do konstytucji i jak na nie wpływa. TK jako „strażnik” konstytucji orzeka m.in. w sprawach zgodności ustaw, umów międzynarodowych i innych aktów prawnych z konstytucją, a zatem kontroluje hierarchiczną zgodność prawa z konstytucją $a^{54}$. Skoro zatem - zgodnie z preambułą konstytucji — wszyscy, którzy ją stosują, powinni to robić, dbając o zachowanie przyrodzonej godności człowieka i skoro godność ta stanowi źródło wolności i praw człowieka i obywatela, a jej poszanowanie i ochrona jest obowiązkiem władz publicznych, to powinna ona zajmować szczególną pozycję w orzecznictwie TK jako wartość przestrzegana i realizowana przez władze publiczne w konkretnych przepisach. Trybunał nieczęsto jednak odnosi się do zasady godności osobowej człowieka. Rzadko jest ona również przywoływana jako źródło aksjologiczne — podstawa interpretacji praw i wolności człowieka, których dotyczy orzeczenie.

Za fundamentalne orzeczenie w tym zakresie należy uznać wyrok TK z 5 marca 2003 r. w sprawie o sygn. akt K 7/0155, w którym rozstrzygnięto kwestię zgodności części przepisów ustawy z dnia 11 kwietnia 1997 r. o ujawnieniu pracy lub służby w organach bezpieczeństwa państwa lub współpracy z nimi w latach 1944-1990 osób pełniących funkcje publiczne ${ }^{56}$. W opinii Rzecznika Praw Obywatelskich [dalej: RPO] — będącego uczestnikiem tego postępowania przed TK — art. $2 \mathrm{w} \mathrm{zw}$. $\mathrm{z}$ art. 40 ust. 3 ww. ustawy w sposób oczywisty naruszały godność osób nią objętych, które nie miały nic wspólnego z istotą służby (pracy) w organach bezpieczeństwa państwa, a zostały potraktowane na równi z rzeczywistymi funkcjonariuszami tych organów. Publikowanie nazwisk takich osób bez indywidualizacji ich czynów miało — w ocenie Rzecznika Praw Obywatelskich — godzić w godność człowieka stanowiącą źródło jego wolności i praw. Rzecznik, powołując się na orzecznictwo TK, przypomniał również, że podanie do publicznej wiadomości informacji o współpracy $\mathrm{z}$ organami bezpieczeństwa państwa musi w praktyce prowadzić do naruszenia dobrego imienia osób objętych tą informacją i nałożenia swoistej kary infamii. W konsekwencji wskazane przepisy powinny — według RPO — zostać uznane za sprzeczne m.in. $\mathrm{z}$ art. 30 konstytucji.

${ }_{53}$ Wyrok TK z 4 kwietnia 2001 r., sygn. akt K 11/00, OSG 2002/2/9.

${ }^{54}$ R. Małajny, Trybunat Konstytucyjny jako strażnik Konstytucji, „Państwo i Prawo” 2016, z. 10, s. 5.

${ }_{55}$ Wyrok TK z 5 marca 2003 r., sygn. akt K 7/01, OTK ZU 2003/3A/19.

${ }_{56}$ Dz.U. z 1999 r. nr 42, poz. 428; nr 57, poz. 618; nr 62, poz. 681 i nr 63, poz. 701; z 2000 r. nr 43, poz. 488; nr 50, poz. 600 oraz z 2002 r. nr 14, poz. 128; nr 74, poz. 676; nr 84, poz. 765; nr 153, poz. 1271 i $\mathrm{nr} 175$, poz. 1434. 
Trybunał Konstytucyjny zwrócił uwagę na dwa aspekty konstytucyjnie gwarantowanej godności człowieka, których podstawę stanowi art. 30 konstytucji. W pierwszym z tych aspektów godność człowieka jest uznawana za wartość transcendentną, pierwotną wobec innych praw i wolności człowieka (których jest źródłem), jest ona „przyrodzona i niezbywalna, towarzyszy człowiekowi zawsze i nie może być naruszona ani przez prawodawcę, ani przez czyny innych podmiotów". W tym znaczeniu człowiek zawsze zachowuje godność i żadne zachowania nie mogą go tej godności pozbawić ani jej naruszyć. W drugim aspekcie — według poglądu Trybunału wyrażonego w przywołanym orzeczeniu — ,godność osobowa jest najbliższa temu, co może być określane prawem osobistości, obejmującym wartości życia psychicznego każdego człowieka oraz te wszystkie wartości, które określają podmiotową pozycję jednostki w społeczeństwie i które składają się, według powszechnej opinii, na szacunek należny każdej osobie". Ponadto - w ocenie Trybunału — jedynie godność w tym drugim aspekcie może zostać naruszona poprzez zachowania innych osób czy w wyniku stosowania określonych regulacji prawnych. Trybunał Konstytucyjny, odwołując się do orzecznictwa konstytucyjnego innych krajów europejskich, podkreślił, że godność człowieka (w jej pierwszym aspekcie) nie może zostać naruszona nawet przez niegodne zachowanie się jej podmiotu, ponieważ godności tego rodzaju nie można odebrać żadnej istocie ludzkiej. Wskazane wcześniej orzeczenie jest o tyle istotne, że Trybunał, rozpoznając zarzut naruszenia art. 30 konstytucji w kontekście rozumienia i wykładni konstytucyjnej godności człowieka, zwykle powołuje się właśnie na ten wyrok ${ }^{57}$.

W późniejszym orzecznictwie Trybunał podnosił też, że konstytucyjna godność człowieka jako przyrodzona i niezbywalna wartość jest charakterystyczna dla każdego człowieka ${ }^{58}$, stanowi immanentną cechę każdej istoty ludzkiej, która nie może być przez człowieka ani zdobyta, ani utracona ${ }^{59}$. TK przypisuje zatem konstytucyjnej godności człowieka te same atrybuty, które personaliści przypisują godności osobowej człowieka. Trybunał potwierdził ponadto, że przedmiotem naruszenia może być tylko godność definiowana jako „prawo osobistości” — prawo do żądania uszanowania przez organy władzy publicznej człowieka, jego wolności, autonomii, określonej

${ }^{57}$ Confer np. orzeczenia TK w sprawach o sygn. akt: K 13/15, K 31/15, K 12/14, Ts 220/10, SK 48/05, SK 43/05, SK 50/06, K 28/05, SK 41/05, SK 14/05, SK 51/05, K 17/05, K 10/04, SK 42/01. Przywołany wyrok TK stanowi fundament wykładni przyrodzonej i niezbywalnej godności osobowej człowieka w polskim orzecznictwie. Nie jest on jednak pozbawiony wad. Trybunał opisał godność człowieka niespójnie z dotychczasowym rozumieniem prezentowanym w doktrynie prawniczej i filozoficznej. Atrybuty godności osobowej zostały w tym wyroku wskazane poprawnie, natomiast sam typ przyrodzonej, niezbywalnej, transcendentnej godności osobowej został określony jako „godność człowieka”. Pojęciu ,godność osobowa” Trybunał przypisał natomiast błędnie cechy godności osobistej. Błąd ten nie wpłynął negatywnie na wykładnię zasady godności człowieka zarówno w tym orzeczeniu, jak i w dalszym orzecznictwie, ponieważ TK dokonał jej poprawnej interpretacji, jedynie nazywając błędnie tę godność „godnością człowieka”. Należy też podkreślić, że zarówno godność osobista, jak i godność osobowościowa czy osobowa są typami godności człowieka.

${ }^{58}$ Wyrok TK z 22 listopada 2016 r., sygn. akt K 13/15, Dz.U. z 2016 r. poz. 2203.

59 Postanowienie TK z 21 września 2011 r., sygn. akt Ts 220/10, Legalis nr 1351593. 
pozycji w społeczeństwie ${ }^{60}$. W swoim orzecznictwie — odnośnie do art. 47 konstytucji (prawo do prywatności) - Trybunał przyjął, że utożsamianie naruszenia każdego prawa i wolności z naruszeniem godności utrudniłoby samoistne stosowanie gwarancji wynikających z art. 30 konstytucji ${ }^{11}$. Nadużywanie tego artykułu w tym kontekście mogłoby prowadzić do spłycenia znaczenia normy wynikającej z tego przepisu: ,niezróżnicowane posługiwanie się takimi słowami, jak [...] «godność ludzka», których jednak nie definiuje się i nie uzasadnia nawet słowem, sprowadza te słowa do pustych frazesów"62.

Trybunał podkreślił, że godność człowieka podlega ochronie bezwzględnej, a zatem $\mathrm{w}$ odniesieniu do niej ma zastosowania mechanizm przewidziany $\mathrm{w}$ art. 31 ust. 3 konstytucji. W przypadku stwierdzenia sprzeczności przepisu z art. 30 konstytucji, nie zachodziłaby już konieczność badania, czy można ją uznać za usprawiedliwioną w kontekście art. 31 ust. 3 konstytucji ${ }^{63}$. W konsekwencji — w ocenie Trybunału „konieczna jest znaczna powściągliwość w treściowym precyzowaniu «godności»»"64.

Istotną tezę $\mathrm{w}$ zakresie konstytucyjnej godności człowieka Trybunał przedstawił w wyroku z 1 września 2006 r., sygn. akt SK 14/05. Skarżący, będący osobą fizyczną, zainicjował postępowanie przed Trybunałem po oddaleniu — ze względu na przedawnienie - jego powództwa o odszkodowanie związane z uszczerbkiem na zdrowiu będącym konsekwencją napromieniowania w trakcie odbywania zasadniczej służby wojskowej. W skardze konstytucyjnej skarżący podniósł, że upływ okresu przedawnienia przed powstaniem faktycznej możliwości wystąpienia na drogę sądową narusza zasady sprawiedliwości społecznej oraz równość wobec prawa, prawo do rozpoznania sprawy w sądzie oraz prawo do naprawienia szkody wyrządzonej przez władzę publiczną. Zdaniem Trybunału, w sprawie tej należało również ustalić, na ile charakter gwarancji konstytucyjnych, udzielonych w zakresie prawa podmiotowego do odszkodowania na tle art. 77 ust. 1 konstytucji, może determinować i uzasadniać ewentualną odrębność pewnych regulacji prawa odszkodowawczego, a na ile powinien uzasadniać nawiązanie do uniwersalnych mechanizmów prawa powszechnego w sferze odpowiedzialności odszkodowawczej ex delicto. Kwestia ta ma znaczenie przede wszystkim w odniesieniu do zasad i przesłanek kompensacji szkody wyrządzonej danej osobie. Jak wskazano w komentowanym orzeczeniu, konieczne jest odniesienie istniejącego rozwiązania także do wartości wyrażonych w art. 30 konstytucji, a zatem do osobowej godności człowieka. Zasada godności człowieka stanowiła zatem podstawę oceny mechanizmu przedawnienia z art. 442 k.c. w odniesieniu do szkody na osobie.

${ }^{60}$ Wyrok TK z 28 czerwca 2016 r., sygn. akt K 31/15, Dz.U. z 2016 r. poz. 1245.

${ }^{61}$ Wyrok TK z 7 października 2015 r., sygn. akt K 12/14, OTK ZU 2015/9A/143.

${ }^{62}$ F.J. Wertz, Totenruche, Leichenwurde und die Mach des Blicks, [w:] Schoene neue Koerperwelten. Die stret um die Ausstellung, red. B. Tag, F.J. Wertz, Stuttgart 2001 (cyt. za: W. Żełaniec, O pojmowaniu godności człowieka, [w:] Szkice o godności człowieka, red. M. Piechowiak, T. Turowski, Zielona Góra 2012, s. 7-8.

${ }^{63}$ Wyrok TK z 7 marca 2007 r., sygn. akt K 28/05, OTK ZU 2007/3A/24.

${ }^{64}$ Wyrok TK z 9 lipca 2009 r., sygn. akt SK 48/05, OTK ZU 2009/7A/108. 
W wyroku w sprawie o sygn. akt SK 14/05 Trybunał wskazał, że „art. 30 Konstytucji wyraża wolność kluczową z punktu widzenia aksjologii konstytucyjnej i nie może być pominięty wtedy, gdy chodzi o ocenę regulacji prawnych nakierowanych na ochronę najbardziej żywotnych interesów każdej osoby" ${ }^{65}$. TK potwierdził, że norma konstytucyjna gwarantująca ochronę godności każdej osoby pełni rolę istotnej dyrektywy konstytucyjnej, z której wynika m.in. wyraźny nakaz stosowania jednolitych kryteriów przy ocenie poprawności rozwiązań odnoszących się do dóbr i wartości o podstawowym znaczeniu dla każdej jednostki. Godność każdej osoby zawsze musi przeważać nad innymi kryteriami, które mogłyby uzasadniać zróżnicowanie poziomu ochrony $^{66} . \mathrm{Z}$ orzecznictwa TK wynika ponadto, że przedmiotem prawa do godności jest — w najogólniejszym ujęciu — zagwarantowanie każdemu człowiekowi możliwości autonomicznego wyrażania swojej osobowości. Przede wszystkim chodzi o to, aby nikt nie był jedynie przedmiotem działań ze strony innych — zwłaszcza władzy publicznej — ani instrumentem wykorzystywanym do realizowania ich celów ${ }^{67}$.

Trybunał istotne stanowisko dotyczące ochrony godności człowieka zawarł również w wyroku z 30 września 2008 r., sygn. akt K 44/07. Postępowanie przed Trybunałem w tej sprawie zostało zainicjowane przez prezesa $\mathrm{SN}$, który wystąpił z wnioskiem o orzeczenie, że art. 122a ustawy z dnia 3 lipca 2002 r. Prawo lotnicze ${ }^{68}$ jest niezgodny z art. 38, art. 31 ust. 3, art. 2, art. 26 oraz art. 30 konstytucji. W zakwestionowanym przepisie, w powiązaniu z art. 18b ustawy z dnia 12 października 1990 r. o ochronie granicy państwoweje, przewidziano możliwość zniszczenia cywilnego statku powietrznego, gdy wymagają tego względy bezpieczeństwa państwa, a statek został użyty do działań sprzecznych z prawem, w szczególności jako środek ataku terrorystycznego z powietrza. W opinii wnioskodawcy zakwestionowana regulacja budziła wątpliwości konstytucyjne m.in. w zakresie ochrony przyrodzonej godności człowieka. Uważał on także, że wbrew nakazowi uznania podmiotowości każdego człowieka kwestionowanymi przepisami udzielono organom władzy publicznej kompetencji do zestrzelenia cywilnego samolotu z pasażerami na pokładzie, jako przedmiotu akcji ratowniczej ukierunkowanej na zminimalizowanie strat na ziemi, pozbawiając te osoby ochrony prawnej. W takiej sytuacji „osoby, które w żaden sposób nie przyczyniły się do stworzenia niebezpieczeństwa zamachu na życie innych ludzi, traktowane są, bez ich zgody i wiedzy, w sposób instrumentalny. W demokratycznym państwie prawa, którego podstawą aksjologiczną jest nienaruszalna i niezbywalna godność każdego człowieka, nie jest dopuszczalne wyposażanie organów administracji publicznej w prawo decydowania o celowym spowodowaniu śmierci niewinnych osób dla ochrony dobra wspólnego, bezpieczeństwa państwa czy nawet życia innych osób".

Odnosząc się do tego zarzutu, TK przywołał swoją dotychczasową linię orzeczniczą w zakresie ochrony godności człowieka, a następnie dokonał jej rozszerzenia.

\footnotetext{
${ }^{65}$ Wyrok TK z 1 września 2006 r., sygn. akt SK 14/05, OTK ZU 2006/8A/97.

${ }^{66}$ Ibidem.

${ }^{67}$ Wyrok TK z 9 lipca 2009 r., sygn. akt SK 48/05, OTK ZU 2009/7A/108.

${ }^{68}$ Dz.U. z 2006 r. nr 100, poz. 696, ze zm.

${ }^{69}$ Dz.U. 2005 r. nr 226, poz. 1944, ze zm.
} 
Trybunał wskazał, że pojęciu „godność ludzka” należy — zgodnie z art. 30 konstytucji - przypisać charakter wartości konstytucyjnej o kardynalnym znaczeniu, jeśli chodzi o aksjologiczny aspekt obecnych rozwiązań konstytucyjnych. Demokratyczne państwo prawne to państwo, którego podstawę stanowi poszanowanie człowieka, a w szczególności poszanowanie i ochrona życia oraz godności ludzkiej. Te dwa dobra są sprzężone w bezpośredni sposób. Trybunał, powołując się na treść preambuły konstytucji, wskazał również, że art. 30 konstytucji jest wiodącym postanowieniem w zakresie wykładni i stosowania wszystkich orzeczeń o prawach, wolnościach i obowiązkach jednostki. Zgodnie ze stanowiskiem Trybunału, potwierdzenie niezbywalności godności człowieka jako zasady konstytucyjnej oraz prawa podmiotowego każdej jednostki ludzkiej — niezależnie od jej kwalifikacji czy stanu psychiczno-fizycznego oraz aktualnej sytuacji życiowej stanowi podstawę uznania jego podmiotowości. Człowiek powinien być traktowany jak wolny, autonomiczny podmiot, zdolny do rozwijania swojej osobowości i kształtowania swojego postępowania. W odniesieniu do zaprezentowanej skargi skutkiem zastosowania kwestionowanego przepisu byłoby „urzeczowienie” znajdujących się na pokładzie samolotu pasażerów, którzy w żaden sposób nie przyczynili się do stworzenia niebezpieczeństwa dla innych osób przez zamachowców: „osoby te stają się jedynie obiektem (przedmiotem) akcji ratunkowej, skierowanej na zapobieganie hipotetycznym, dalszym i prawdopodobnie większym stratom, jakie mogłoby wywołać celowane uderzenie terrorystyczne. $Z$ gruntu fałszywy jest przy tym argument, iż pasażerowie i załoga samolotu RENEGADE znaleźli się w takiej sytuacji wyłącznie wskutek bezprawnego działania zamachowców; pośrednio jest to bowiem przejawem niepowodzenia państwa w realizacji pozytywnych obowiązków ochronnych".

$\mathrm{Z}$ orzecznictwa Trybunału wynika zatem, że godność stanowi wartość transcendentną, pierwotną wobec innych praw i wolności człowieka. Jako przyrodzona i niezbywalna towarzyszy ona człowiekowi zawsze i nie może być naruszona ani przez prawodawcę, ani przez czyny innych podmiotów, ani przez niego samego. Godność człowieka podlega przy tym ochronie bezwzględnej i działanie skierowane przeciwko niej nie podlega ocenie z perspektywy proporcjonalności i nie może być w żaden sposób i w żadnym stopniu legitymowane. Istotą zasady godności człowieka jest przede wszystkim zagwarantowanie każdemu pozycji uniemożliwiającej potraktowanie go jak przedmiotu działań ze strony innych i instrumentu w urzeczywistnianiu jakichkolwiek celów. Z prawa tego wynika zakaz jakiegokolwiek uprzedmiotowienia człowieka i każdorazowy nakaz jego podmiotowego traktowania.

\section{ZNACZENIE POJECIA „GODNOŚĆ CZLOWIEKA” W ORZECZNICTWIE SĄDU NAJWYŻSZEGO}

Nie odbierając Trybunałowi Konstytucyjnemu pozycji „strażnika” konstytucji, należy wskazać, że to Sąd Najwyższy sprawuje nadzór nad działalnością sądów powszechnych i wojskowych w zakresie orzekania (art. 183 ust. 1 konstytucji). Jest organem władzy sądowniczej, powołanym m.in. do sprawowania wymiaru sprawiedliwości przez zapewnienie — w ramach nadzoru — zgodności z prawem oraz jednolitości 
orzecznictwa sądów powszechnych i wojskowych przez rozpoznawanie kasacji i innych środków odwoławczych oraz podejmowanie uchwał rozstrzygających zagadnienia prawne $^{70}$. SN pełni zatem nadzór judykacyjny, tj. merytoryczny nad orzecznictwem, i ma zapobiegać powstawaniu szkodliwych dla bezpieczeństwa prawnego rozbieżności interpretacyjnych ${ }^{71}$. W konsekwencji również w swoim orzecznictwie powinien on uwzględniać zasadę godności człowieka w procesie wykładni przepisów prawa.

Sąd Najwyższy nawiązywał do godności człowieka najczęściej w odniesieniu do godności osobistej i ochrony dóbr osobistych w kontekście prawa cywilnego. Godność osobista stanowi jednak jedynie fragment godności osobowej człowieka, jedno z praw, które z godności osobowej wynika. Analizie poddano przede wszystkim orzeczenia SN, w których powoływał się on wprost na przepis art. 30 konstytucji. SN niejednokrotnie zrównywał art. 30 konstytucji z konstytucyjnym źródłem dóbr osobistych. Art. 30 konstytucji jest czasami błędnie uznawany za przepis bezpośrednio chroniący dobra osobiste ${ }^{72}$, a godność wskazana w preambule i art. 30 konstytucji jest utożsamiana z godnością osobistą czy osobowościową, które - co prawda — mają swoje źródło w godności osobowej, ale nie są z nią tożsame ${ }^{73}$. Takie rozumienie konstytucyjnej godności człowieka jest błędne i pozbawia zasadę godności człowieka atrybutów, które stanowią o jej pierwszeństwie przed pozostałymi zasadami budującymi system prawny Rzeczypospolitej.

W wyroku z 2 października 2007 r., sygn. akt II CSK 269/07, SN wskazał, że obowiązek władz publicznych do poszanowania i ochrony godności człowieka jest szczególnie istotny tam, gdzie państwo działa $\mathrm{w}$ ramach imperium, realizując swoje zadania represyjne, których wykonanie nie może prowadzić do większego ograniczenia praw człowieka i jego godności, niż to wynika z zadań ochronnych i celu zastosowanego środka ${ }^{74}$. SN podkreślił jednocześnie, że legitymacji państwa do karania obywateli towarzyszy obowiązek zapewnienia godziwych warunków wykonywania kary. Państwo może wykonywać swoje uprawnienia do karania obywateli jedynie z poszanowaniem ich godności osobowej. Podobnie interwencja władzy publicznej przez jedynie ograniczenie konstytucyjnych wolności człowieka (np. przez poddanie go przymusowemu leczeniu odwykowemu) jest limitowana przez godność osobową człowieka. Właśnie we wszystkich sferach represyjnego działania państwa sądy i trybunały powinny jak najczęściej odwoływać się do konstytucyjnej zasady godności człowieka ograniczającej państwo w jego imperium. Sąd Najwyższy w swoim orzecznictwie stwierdził ponadto, że poszanowanie godności jest nakazem nie tylko prawnym, wynikającym z art. 30 konstytucji, ale również moralnym ${ }^{75}$. Godność człowieka nie została nadana przepisami konstytucji, w tym akcie jedynie zadeklarowano prymat godności w sferze interpretacji pozostałych praw.

\footnotetext{
${ }^{70}$ Ustawa z dnia 23 listopada 2002 r. o Sądzie Najwyższym, Dz.U. nr 240, poz. 2052, ze zm.

71 Vide Prawo o ustroju sądów powszechnych. Komentarz, red. A. Górski, Warszawa 2013, s. 33.

72 Postanowienie SN z 7 lutego 2007 r., sygn. akt III KK 236/06.

73 Wyrok SN z 30 listopada 2006 r., sygn. akt I CSK 269/06, Legalis nr 161066.

74 Postanowienie SN z 20 listopada 2013 r., sygn. akt I CSK 82/13, Legalis nr 1060991.

75 Wyrok SN z 11 kwietnia 2006 r., sygn. akt I PK 169/05.
} 
Obowiązek respektowania godności innych osób nie wynika wyłącznie z przepisów konstytucji, ale także z innych powszechnie akceptowanych systemów etycznych. W wyroku z 28 maja 2008 r., sygn. akt SNO 34/08, SN wyraził interesujący pogląd, że chociaż w ustawie o ustroju sądów powszechnych nie przewidziano odpowiedniego stosowania przepisów kodeksu karnego w postępowaniu dyscyplinarnym dotyczącym sędziów, należy przestrzegać w tym postępowaniu zawartego w art. 53 k.k. zakazu wymierzania kary przekraczającej swoją dolegliwością stopień winy sprawcy, ponieważ zakaz ten wynika już z konstytucyjnej zasady poszanowania godności człowieka, czyli z art. 30 konstytucji. Takie cele kary dyscyplinarnej, jak prewencja indywidualna i ogólna, muszą zostać podporządkowane zakazowi wymierzania kary dyscyplinarnej przekraczającej swoją dolegliwością stopień winy obwinionego. SN uznał, że z konstytucyjnej godności osobowej człowieka wypływa zakaz wymierzania przez państwo kary przekraczającej swoją dolegliwością stopień winy naruszyciela ustanowionego przez nie prawa. Doprecyzowanie tej dyrektywy w przepisach prawa materialnego nie jest konieczne, ponieważ przeciwne założenie byłoby sprzeczne z podstawową zasadą konstytucyjną. Dolna granica wymiaru kary jest zatem zależna przede wszystkim od celów zapobiegawczych i wychowawczych, a także od potrzeb w zakresie kształtowania świadomości prawnej społeczeństwa (art. 53 k.k.).

Przywołane cele polityki karnej mogą być realizowane poprzez karę wymierzoną sprawcy, ale jedynie w zakresie, w którym kara ta nie narusza jego przyrodzonej i niezbywalnej godności. Kara ta powinna być nie tylko humanitarna, ale i dostosowana do stopnia winy. Przekroczenie przez sąd stopnia winy sprawcy i wymierzenie nadmiernie surowej kary np. w celu zniechęcenia innych do popełnienia podobnych czynów zabronionych (cel prewencyjny) stanowi działanie skierowane przeciwko konstytucyjnej godności człowieka.

Tezę ważną w kontekście zrozumienia istoty godności człowieka przedstawił SN w wyroku z 25 kwietnia 1989 r., sygn. akt I CR 143/8976, wydanym na długo przed ukształtowaniem obecnej konstytucyjnej zasady godności człowieka. W sprawie tej wnioskodawcy wytoczyli powództwo przeciwko Zrzeszeniu Transportu Prywatnego w K. o ochronę dóbr osobistych. Naruszenie miało polegać m.in. na naruszeniu prawa powodów do wolności dokonywania swobodnych wyborów. SN zajął się tą sprawą wskutek rewizji wniesionej przez wspomniane przedsiębiorstwo. Sąd w przywołanym orzeczeniu podniósł, że pozbawienie człowieka przysługujących mu uprawnień godzi w jego godność. Godności osobowej człowieka nie można naruszyć poprzez pozbawienie go uprawnień i wolności. Takie niewłaściwe zachowanie jakiegokolwiek podmiotu nie narusza, ani tym bardziej nie pozbawia człowieka godności, a jedynie w nią godzi, tzn. stanowi zachowanie skierowane przeciwko niej, a zatem jest sprzeczne $\mathrm{z}$ podstawową wartością konstytucyjną ${ }^{77}$.

76 Wyrok SN z 25 kwietnia 1989 r., sygn. akt I CR 143/89.

77 W dalszej części orzeczenia SN nie zachował przywołanego wcześniej spójnego rozumienia godności, odniósł się bowiem do godności osobistej człowieka, wskazując na możliwość jej naruszenia, które dodatkowo należy oceniać w kontekście odczuć opinii publicznej. 
W przywołanych orzeczeniach SN uzupełnił eksplikację zakresu godności człowieka przedstawioną $\mathrm{w}$ orzeczeniach TK i określił obowiązki władz publicznych $\mathrm{w}$ zakresie jej poszanowania. Państwo, realizując swoje zadania, w szczególności zadania represyjne, musi pamiętać o limitującej funkcji godności, ponieważ korzystanie z uprawnienia do karania obywateli jest sprzężone z obowiązkiem zapewnienia godziwych warunków wykonywania kary. Co więcej, godność człowieka nie tylko limituje stosowanie norm prawnych, ale również pozwala na ich wyprowadzenie w razie bierności ustawodawcy w zakresie stanowienia o prawach i wolnościach człowieka i obywatela. Tak właśnie uczynił SN w przywołanym wyroku o sygn. akt SNO 34/08, stwierdzając, że zakaz wymierzania kary przekraczającej swoją dolegliwością stopień winy sprawy wynika wprost z konstytucyjnej zasady poszanowania godności człowieka.

\section{WNIOSKI KOŃCOWE. PROPOZYCJA TESTU ZGODNOŚCI REGULACJI Z ZASADA GODNOŚCI CZŁOWIEKA}

Godność człowieka powinna być fundamentem wykładni wszystkich praw człowieka, jak również wszystkich przepisów, które mają urzeczywistniać prawa i wolności człowieka w systemie prawa. Odniesienia do godności człowieka przewijają się w orzeczeniach TK i SN, ale wydaje się, że zasada godności człowieka nie zajmuje należnej jej fundamentalnej pozycji w orzecznictwie. Trudno powiedzieć, czy wynika to z niepostrzegania przez sądy i trybunały godności człowieka jako zasady, którą należy odnaleźć w każdym z praw i wolności, czy w praktyce rzadko zachodzi konieczność powołania się na tę zasadę, np. z uwagi na możliwość dokonania prawidłowej wykładni przepisów w innym kontekście. Być może ciągłe powoływanie się na godność człowieka spowodowałoby negatywny efekt i pozbawiło godność znaczenia, sprowadzając ją do roli pustego frazesu. Bez wątpienia jednak, żeby godność człowieka mogła być jedną z matryc dekodowania przepisów prawnych przez sądy i trybunały, musi ona być przede wszystkim elementem budującym normy. W konsekwencji konstytucyjna godność człowieka najpierw powinna być uwzględniana w procesie projektowania i stanowienia przepisów przez ustawodawcę.

Oceniając zgodność każdej projektowanej regulacji z zasadą przyrodzonej i niezbywalnej godności człowieka, należy wziąć pod uwagę treść tej zasady. Godność człowieka jest przyrodzona, a zatem jakimikolwiek projektowanymi przepisami nie można nadać człowiekowi godności, można ją jedynie deklarować. Godność ta jest niezbywalna, a zatem człowiek nie może się jej zrzec w całości ani w części. Godność człowieka jako właściwy każdej osobie rdzeń człowieczeństwa jest nienaruszalna i żadne działania nie mogą sprawić, że człowiek utraci godność i immanentnie związane z nią prawa i wolności. Możliwe jest natomiast podjęcie działań skierowanych przeciwko godności człowieka, tj. działań w swojej istocie negujących godność osoby. Takie zachowanie będzie zawsze niezgodne z konstytucyjną zasadą godności, a w konsekwencji będzie implikowało konieczność podjęcia przez władze publiczne działań zmierzających do zapewnienia poszanowania i ochrony godności człowieka. Obowiązek ochrony godności człowieka przez władze publiczne jest ciągle aktualny, państwo powinno nie tylko 
reagować na działania przeciwko godności człowieka, ale również im zapobiegać ${ }^{78}$. Bierność władz publicznych, zaniechanie gwarancji zachowania godności człowieka i niezapobiegnięcie sprzecznym z godnością człowieka działaniom również są sprzeczne z zasadą godności człowieka.

W konsekwencji zarówno obowiązujące, jak i projektowane regulacje powinny zostać poddane testowi zgodności z zasadą godności człowieka.

Po pierwsze, test ten powinien obejmować zbadanie, czy w obowiązujących lub projektowanych regulacjach nie odmówiono w jakimkolwiek zakresie przyrodzonego charakteru godności w odniesieniu do każdego człowieka lub przyrodzonego charakteru praw nierozerwalnie z godnością związanych (np. prawa do życia). Taka deklaracja byłaby sprzeczna z treścią zasady godności człowieka — oraz z wynikającą z niej przyrodzonością godności człowieka - i w konsekwencji nieskuteczna. Fakt, że takie regulacje byłyby nieskuteczne, nie oznacza, że mogłyby zostać zignorowane. Sama taka deklaracja państwa wyrażona w formie aktu prawnego stanowiłaby działanie skierowane przeciwko godności człowieka przejawiające się w nieudolnej próbie podważenia przyrodzonego charakteru godności człowieka, którego przecież ustawodawca nie stanowi, a jedynie je deklaruje ${ }^{79}$.

Po drugie, należy zbadać, czy w obowiązujących lub projektowanych regulacjach respektowana jest niezbywalność i nienaruszalność godności człowieka ze szczególnym uwzględnieniem jej niepodzielności i niestopniowalności. W przepisach nie można wprowadzać jakiegokolwiek trybu uszczuplenia przyrodzonej i niezbywalnej godności człowieka, ani przewidywać jakichkolwiek trybów chociażby częściowego zrzeczenia się tej godności. Godność jest niepodzielna i niemożliwe jest wydzielenie jej fragmentów. W konsekwencji niemożliwe jest jakiekolwiek jej uszczuplenie. Akceptacja poglądu przeciwnego podważa status, jaki nadano godności człowieka w konstytucji. Takie przepisy będą również faktycznie nieskuteczne (nie może dojść do zbycia czy naruszenia godności człowieka w sensie opisowym), treściowo sprzeczne z konstytucyjną zasadą godności człowieka, nie będą mogły też być stosowane przez władze publiczne jako sprzeczne z zasadą praworządności (co sprowadza się przede wszystkim do sprzeczności z ustawą zasadniczą, a zatem faktyczną derogacją takiej normy wskutek niezgodności z aktem wyższego rzędu - konstytucją). Podobnie jak w przypadku pierwszego warunku sama taka deklaracja państwa wyrażona w formie aktu prawnego stanowiłaby działanie skierowane przeciwko godności człowieka.

Po trzecie, obowiązujące lub projektowane regulacje nie mogą zawierać przepisów pozwalających na podjęcie przez jakikolwiek podmiot (prywatny czy państwowy)

${ }^{78}$ Ustawodawca w art. 30 konstytucji wskazał wprost, że obowiązkiem władz publicznych jest zarówno poszanowanie godności człowieka, jak i jej ochrona. Zaniechanie władz publicznych i niedopełnienie obowiązku ochrony godności człowieka jest takim samym naruszeniem konstytucji, jak bezpośrednie nieposzanowanie godności przez te władze.

${ }^{79} \mathrm{~W}$ przywołanym wcześniej aspekcie opisowym godność pozostaje nienaruszalna — rdzeń człowieczeństwa każdej osoby pozostaje nienaruszony. Podejmując wskazane zachowanie, władze publiczne dopuszczają się pogwałcenia nienaruszalności normatywnej, tj. postępują wbrew nakazowi poszanowania nieinstrumentalności godności. 
jakichkolwiek działań, które byłyby skierowane przeciwko godności człowieka. Godność człowieka jest nienaruszalna (w aspekcie opisowym), a władze publiczne nie mogą podejmować działań podważających jej nienaruszalność. Ustawodawca nie może nikogo wyposażyć w kompetencję do jej naruszenia ani do podejmowania jakichkolwiek działań skierowanych przeciwko niej. Nienaruszalność w aspekcie normatywnym oznacza wszak skierowany do władz publicznych nakaz respektowania nienaruszalności godności połączony z obowiązkiem jej ochrony i poszanowania, co w sposób oczywisty wyklucza możliwość wyposażenia kogokolwiek przez władze publiczne w kompetencje do podejmowania działań niezgodnych z godnością człowieka. Regulacje takie należałoby odczytywać wyłącznie jako podważanie konstytucyjnej zasady godności człowieka.

Po czwarte, w razie wprowadzenia przepisów niedookreślonych lub innych stwarzających ryzyko nadużycia, a w konsekwencji podjęcia przez jakiekolwiek podmioty działań, które byłyby skierowane przeciwko godności człowieka, ustawodawca powinien wraz z nimi wprowadzić skuteczne normy uprawniające i zobowiązujące władze publiczne do szczególnej ochrony godności człowieka przed zjawiskiem nadużywania lub błędnego stosowania tych przepisów. Optymalne regulacje w tym zakresie powinny skutecznie zapobiegać nadużyciu lub ich błędnemu stosowaniu. Gdyby jednak doszło do błędnego zastosowania lub nadużycia tych przepisów - a w konsekwencji działań sprzecznych z zasadą godności człowieka — kompletny i spójny system prawny powinien zawierać regulacje pozwalające na niezwłoczną i skuteczną restytucję stanu zgodnego z prawem, a ponadto na wyrównanie ewentualnej szkody lub krzywdy.

Wreszcie za sprzeczne z konstytucyjną zasadą godności człowieka należy uznać jakiekolwiek regulacje — chociażby spełniające wymienione wcześniej kryteria — prowadzące w sposób jawny lub ukryty do postawienia jakiejś grupy ludzi lub chociażby jednego człowieka w sytuacji, w której staliby się oni przedmiotem działań ze strony innych (w tym państwa) lub byli jedynie instrumentem ich działań. Niedopuszczalna w kontekście zasady godności człowieka jest jakakolwiek depersonifikacja czy reifikacja człowieka niezależnie od jej podstaw i przyczyn. Takiego uprzedmiotowienia człowieka nie można $\mathrm{w}$ żaden sposób tłumaczyć, nie istnieją żadne kryteria pozwalające na jego wprowadzenie w życie w sposób zgodny z przyrodzoną i niezbywalną godnością człowieka.

BIBLIOGRAFIA

ŹRÓDŁA

Konstytucja Rzeczypospolitej Polskiej z dnia 2 kwietnia 1997 r., Dz.U. nr 78, poz. 483.

Ustawa z dnia 23 kwietnia 1964 r. — Kodeks cywilny, Dz.U. nr 16, poz. 93.

Ustawa z dnia 6 czerwca 1997 r. — Kodeks karny, Dz.U. nr 88, poz. 553.

ORZECZNICTWO TRYBUNAŁU KONSTYTUCYJNEGO

Wyrok TK z 23 marca 1999 r., sygn. akt K 2/98, OTK 1999/3/38.

Wyrok TK z 4 kwietnia 2001 r., sygn. akt K 11/2000, Dz.U. z 2001 r. nr 32, poz. 386. 
Wyrok TK z 5 marca 2003 r., sygn. akt K 7/01, OTK ZU 2003/3A/19.

Wyrok TK z 14 lipca 2003 r., sygn. akt SK 42/01, OTK ZU 2003/6A/63.

Wyrok TK z 22 lutego 2005 r., sygn. akt K 10/04, OTK ZU 2005/2A/17.

Wyrok TK z 11 maja 2005 r., sygn. akt K 18/04, OTK ZU 2005/5A/49.

Wyrok TK z 20 marca 2006 r., sygn. akt K 17/05, OTK ZU 2006/3A/30.

Wyrok TK z 23 maja 2006 r., sygn. akt SK 51/05, Dz.U. z 2006 r. nr 94, poz. 657.

Wyrok TK z 1 września 2006 r., sygn. akt SK 14/05, OTK ZU 2006/8A/97.

Wyrok TK z 24 października 2006 r., sygn. akt SK 41/05, Dz.U. z 2006 r. nr 198, poz. 1464.

Wyrok TK z 7 marca 2007 r., sygn. akt K 28/05, OTK ZU 2007/3A/24.

Wyrok TK z 10 lipca 2007 r., sygn. akt SK 50/06, Dz.U. z 2007 r. nr 128, poz. 903.

Wyrok TK z 12 maja 2008 r., sygn. akt SK 43/05, Dz.U. z 2008 r. nr 90, poz. 560.

Wyrok TK z 9 lipca 2009 r., sygn. akt SK 48/05, OTK ZU 2009/7A/108.

Wyrok TK z 7 października 2015 r., sygn. akt K 12/14, OTK ZU 2015/9A/143.

Wyrok TK z 28 czerwca 2016 r., sygn. akt K 31/15, Dz.U. z 2016 r. poz. 1245.

Wyrok TK z 22 listopada 2016 r., sygn. akt K 13/15, Dz.U. z 2016 r. poz. 2203.

Postanowienie TK z 21 września 2011 r., sygn. akt Ts 220/10, Legalis nr 1351593.

\section{ORZECZNICTWO SĄDU NAJWYŻSZEGO}

Wyrok SN z 25 kwietnia 1989 r. I CR 143/89, OSP 1990/9/330.

Wyrok SN z 11 kwietnia 2006 r., sygn. akt I PK 169/05.

Wyrok SN z 30 listopada 2006 r., sygn. akt I CSK 269/06, Legalis nr 161066.

Wyrok SN z 21 marca 2007 r., sygn. akt I CSK 292/06, Legalis nr 156746.

Wyrok SN z 27 czerwca 2012 r., sygn. akt IV CSK 389/11, Legalis nr 551906.

Wyrok SN z 14 stycznia 2015 r., sygn. akt II CSK 296/14, Legalis nr 1200679.

Postanowienie SN z 7 lutego 2007 r., sygn. akt III KK 236/06.

Postanowienie SN z 20 listopada 2013 r., sygn. akt I CSK 82/13, Legalis nr 1060991.

\section{PIŚMIENNICTWO}

Borkowski P., Godność osoby ludzkiej - zasada zasad społecznych, [w:] Jan Pawet II Promotorem godności człowieka, red. A. Bałabucha, Papieski Wydział Teologiczny, Świdnica 2007.

Borski M., Godność czlowieka jako wartość uniwersalna, „Przegląd Prawa Publicznego” 2014, nr 3.

Bosek L., Gwarancje godności ludzkiej i ich wplyw na polskie prawo cywilne, Wydawnictwo Sejmowe, Warszawa 2012

Complak K., Uwagi o godności człowieka oraz jej ochrona w świetle nowej Konstytucji, „Przegląd Sejmowy" 1998, nr 5.

Complak K., Godność nie jest dobra na wszystko. Propozycja uporządkowania materii, [w:] Minikomentarz dla maksiprofesora: ksiega jubileuszowa profesora Leszka Garlickiego, red. M. Zubik, Warszawa 2016.

Czekalski R., Personalistyczna pedagogika wychowawcza Jana Pawła II, „Warszawskie Studia Teologiczne" 2008, t. XXI.

Górski A., Prawo o ustroju sądów powszechnych. Komentarz, C.H. Beck, Warszawa 2013.

Granat M., Godność człowieka z art. 30 Konstytucji RP jako wartość i jako norma prawna, „Państwo i Prawo” 2014, z. 8.

Kant I., Uzasadnienie metafizyki moralności, Państwowe Wydawnictwo Naukowe, Warszawa 1971.

Ossowska M., Normy moralne w obronie godności człowieka, „Etyka” 1969, nr 5. 
Piechowiak M., Dobro wspólne jako fundament polskiego porządku konstytucyjnego, Biuro Trybunału Konstytucyjnego, Warszawa 2012.

Piechowiak M., Filozofia praw czlowieka - Prawa człowieka w świetle ich międzynarodowej ochrony, Towarzystwo Naukowe Katolickiego Uniwersytetu Lubelskiego, Lublin 1999.

Piechowiak M., Klasyczna koncepcja osoby jako podstawa pojmowania praw człowieka. Wokót Tomasza z Akwinu i Immanuela Kanta propozycji ugruntowania godności człowieka, [w:] Prawo naturalne - natura prawa, red. P. Dardziński, F. Longchamps de Bérier, K. Szczucki, C.H. Beck, Warszawa 2011.

Piechowiak M., Prawne a pozaprawne pojęcia dobra wspólnego, [w:] Dobro wspólne. Teoria i praktyka, red. W. Arndt, F. Longchamps de Bérier, K. Szczucki, Wydawnictwo Sejmowe, Warszawa 2013.

Piechowiak M., Stużebność państwa wobec człowieka i jego praw jako naczelna idea Konstytucji RP, „Przegląd Sejmowy” 2007, nr 4.

Rodziński A., Osoba, moralność, kultura, Lublin 1989.

Rodziński A., U podstaw kultury moralnej, Ośrodek Dokumentacji i Studiów Społecznych, Warszawa 1999.

Safjan M., Bosek L., Konstytucja RP, t. I, Komentarz, C.H. Beck, Warszawa 2016.

Spaemann R., Osoby - o różnicy między kimś a czymś, Oficyna Naukowa, Warszawa 2001.

Stownik języka polskiego, t. 1: A-K, red. M. Szymczak, Wydawnictwo Naukowe PWN, Warszawa 1988.

Wojewoda M., Natura ludzka i wolność w ujęciu Roberta Spaemanna, [w:] Szkice o godności człowieka, red. M. Piechowiak, T. Turowski, Oficyna Wydawnicza Uniwersytetu Zielonogórskiego, Zielona Góra 2012.

Wojtyła K., Człowiek w polu odpowiedzialności, Ośrodek Dokumentacji Pontyfikatu Fundacji Jana Pawła II, Rzym-Lublin 1991.

Wojtyła K., Rozważania o istocie człowieka, Wydawnictwo WAM, Kraków 2003.

Zdziennicki B, Preambuła Konstytucji Rzeczpospolitej Polskiej, Biuro Trybunału Konstytucyjnego, Warszawa 2009.

Żełaniec W., O pojmowaniu godności człowieka, [w:] Szkice o godności człowieka, red. M. Piechowiak, T. Turowski, Oficyna Wydawnicza Uniwersytetu Zielonogórskiego, Zielona Góra 2012. 